\title{
Comparison of Depression Rate Between the First- and Final-Year Nursing Students in Kermanshah, Iran
}

This article was published in the following Dove Press journal:

Psychology Research and Behavior Management

\author{
Maryam Janatolmakan (iD) \\ Bahare Andaieshgar (D) \\ Amir Aryan (D) ${ }^{2}$ \\ Faranak Jafari' \\ Alireza Khatony $\mathbb{D D}^{3}$ \\ 'Clinical Research Development Center, \\ Imam Reza Hospital, Kermanshah \\ University of Medical Sciences, \\ Kermanshah, Iran; ${ }^{2}$ Student Research \\ Committee, Kermanshah University of \\ Medical Sciences, Kermanshah, Iran; \\ ${ }^{3}$ Health Institute, Social Development \\ and Health Promotion Research Center, \\ Kermanshah University of Medical \\ Sciences, Kermanshah, Iran
}

Background: Depression can affect nursing students' quality of life, academic performance, and clinical self-efficacy and may interfere with their relationship with patients. The purpose of this study was to compare of depression rate between the first- and final-year nursing students in Kermanshah, Iran.

Methods: In this descriptive-analytical study, 60 first-year and 42 last-year nursing students were enrolled. The participants were chosen using the census sampling method. The data collection tool was Beck's Depression Inventory. Data were analyzed using descriptive and inferential statistics.

Results: In our study, $61.7 \%(\mathrm{n}=37)$ of the first year and $38.1 \%(\mathrm{n}=16)$ of the last year students had varying degrees of depression. The rate of depression was significantly higher in first-year students than last-year students $(p=0.013)$.

Discussion: Given the relatively high rate of depression among nursing students, the need for targeted planning to control their mental health, especially in the first year of study, is of importance.

Keywords: prevalence, depression, nursing, students

\section{Introduction}

According to the prediction of WHO, depression will be the second leading cause of disabilities of all ages in the whole world by $2020 .{ }^{1}$ Depression is one of the most common problems that students encounter during their studies. ${ }^{2}$ It is associated with sleep disturbances and decreased self-care, self-esteem, and concentration. ${ }^{3,4}$ Depression is the cause of many physical disorders, including fatigue, insomnia, decreased libido, diarrhea, digestive disorders, and disruption of biological rhythms. ${ }^{5}$ Depression can affect medical and nursing students' quality of life, academic performance, home staying environment, and clinical self-efficacy and may interfere with their relationship with patients." ${ }^{6,7}$ Among the various fields of medical sciences, nursing students face more stressors while studying and are more at risk of depression than other students. ${ }^{8,9}$ Depression in nursing students can be caused by factors such as academic concerns, problems with clinical practice, and personal issues. ${ }^{10}$ Evidence suggests that nursing students are more likely to be depressed in their first year of education and at the time they begin clinical practice than at any other period. ${ }^{11,12}$ Students also encounter several stressors upon beginning clinical education, the most common of which can be related to death of patients, observation of patients' suffering, communication problems with physicians, and concerns about mistakes while caring for patients. ${ }^{13,14}$ Depression rates among nursing students in different countries vary 
between $10 \%$ and $70 \%{ }^{3,8,15-18}$ A meta-analysis reported the pooled prevalence of depression among nursing students was $34 \%$ worldwide. ${ }^{19}$ Given the lack of data regarding the rate of depression among freshman and senior nursing students at Kermanshah University of Medical Sciences and considering the educational risks of depression, the researchers aimed to compare the rate of depression in first- and final-year nursing students.

\section{Materials and Methods Study Design}

This was a cross-sectional, descriptive, analytical study carried out among freshman and senior nursing students.

\section{Study Questions}

The researchers sought to answer the following question: (1) what is the frequency of depression in the first- and fourthyear nursing students? and (2) What is the relationship between the level of depression and gender, marital status, age, place of residence, interest in nursing, and household monthly income in the first- and fourth-year students?

\section{Sample and Sampling Method, and Data Gathering}

The study population consisted of all nursing students studying at school of nursing and midwifery, Kermanshah University of Medical Sciences, Iran. The samples included all the freshman and senior nursing students $(n=102)$ who were selected by the census sampling method. The inclusion criteria included consent to participate in the study and lack of hypothyroidism, chronic illnesses (self-report), mental illnesses (such as depression, anxiety, or obsession) (selfreport), or history of consumption of drugs affective mental status (self-report). After receiving approval from the Ethics Committee of Kermanshah University of Medical Sciences, the researchers obtained the freshman and senior students' roster and met the students based on their schedule. After explaining the study objective and obtaining written informed consent, the questionnaires were distributed among the students.

\section{Measurement Tool}

Data were collected using a demographic information form and Beck's Depression Inventory (BDI). The demographics form included items on age, sex, marital status, semester, place of residence, household monthly income, and interest in nursing. BDI is one of the most commonly used psychometric tests prepared by Beck to measure the severity of depression $^{20,21}$ and the reliability and validity of this tool has been confirmed in various studies. ${ }^{22,23}$ The psychometric properties of the Persian version of this tool have been confirmed by Ghassemzadeh et al (2005), and the internal consistency of the questionnaire has been estimated to be 0.74 by Cronbach's alpha method. ${ }^{24}$ This questionnaire consists of 21 self-report multiple-choice questions that determine affective, cognitive, somatic and vegetative symptoms as well as selfcriticism level of the individual. ${ }^{25}$ The score of each question ranges from zero to three and the total score of the questionnaire ranges from 0 to 63 . Subjects are placed in one of the categories of "no depression or minimal depression" (score 0-9), "mild depression" (score 10-18), "moderate depression" (score 19-29), and "severe depression" (score 30-63).

\section{Data Analysis}

Data were analyzed by the SPSS v.18.0 software using descriptive and inferential statistics. Chi-square test was used to compare the level of depression between first- and fourth-year students in terms of nominal variables (including sex, marital status, place of residence, field of study, and history of family illnesses). Mann-Whitney $U$-test was used to compare the rate of depression among the first- and fourth-year students in terms of ordinal variables (including age and household monthly income). Mann-Whitney $U$-test was run to examine the relationship between the level of depression and binary qualitative variables (including gender, marital status, place of residence, and interest in the field). Finally, Kruskal-Wallis test was used to investigate the relationship between depression and multivariable qualitative variables (including age group and household income). Multiple logistic regression was used to investigate the relationship between depression and demographic variables in freshmen and senior students. The significance level was considered less than 0.05 .

\section{Ethical Considerations}

Ethics Committee of the University approved the study with a code of IR.KUMS.REC.1398.154. Written informed consent was obtained from all the participants, and they were assured of the confidentiality of the data.

\section{Results}

A total of 110 students participated in the study, eight of whom were excluded due to incomplete completion of the questionnaire (response rate: $92.7 \%$ ). The mean age of the students was $21.5 \pm 1.8$ years, and $53.0 \%(n=54)$ of them 
were aged 21-23 years. 55.9\% $(\mathrm{n}=57)$ of the samples were female and $90.2 \%(n=92)$ were single. Also, $58.8 \%$ $(n=60)$ of the students were freshman students and $41.2 \%$ $(\mathrm{n}=42)$ were senior students. What is more, $66.7 \%(\mathrm{n}=$ 68 ) of the students were living in dormitories and $68.6 \%$ $(\mathrm{n}=70)$ were interested in nursing (Table 1).

Results showed that $61.7 \%(n=37)$ of the freshman students were depressed, and among these, $70.3 \%(n=26)$ had mild depression, $24.3 \%(\mathrm{n}=9)$ moderate depression, and $4.0 \%(n=2.5)$ severe depression. Of the senior students, 38.1\% $(\mathrm{n}=16)$ had depression, $81.3 \%(\mathrm{n}=13)$ of whom had mild depression and $18.7 \%(n=3)$ had moderate depression. Mann-Whitney $U$-test showed a significant difference in the rate of depression between the first- and fourth-year students $(p=0.013)$. In freshmen students, depression was not significantly different in terms of gender, marital status, age, place of residence, and interest in nursing, but this difference was significant in terms of household monthly income, such that students whose monthly household income was less than $\$ 300$ showed the highest level of depression, and those with a monthly income of $\$ 300$ - $\$ 600$ had the lowest rates of depression. Also, in the fourth-year students, there was no significant difference in the rate of depression based on the variables of sex, marital status, age, place of residence, interest in nursing and household monthly income (Tables 2 and 3 ).

\section{Discussion}

The purpose of our study was to compare the rate of depression between the first- and final-year nursing students. Results showed that almost half of the nursing students had some degrees of depression and most first- and fourth-year nursing students suffered from moderate and mild depression, respectively. Depression is prevalent among nursing students in different countries (between 10\% and 70\%). ${ }^{3,8,17,18}$ The high rate of depression in our study is alarming and shows that health care authorities at the university should take appropriate measures to manage depression among students.

In our study, there was a statistically significant difference in the rate of depression by school year, with the rate of

Table I Demographic Characteristics of First- and Final-Year Nursing Students

\begin{tabular}{|c|c|c|c|c|c|}
\hline \multicolumn{2}{|l|}{ Variables } & $\begin{array}{l}\text { Total Number } \\
\text { (\%) }\end{array}$ & $\begin{array}{l}\text { First Year Number } \\
\text { (\%) }\end{array}$ & $\begin{array}{l}\text { Final Year Number } \\
\text { (\%) }\end{array}$ & $\begin{array}{l}\text { Test } \\
\text { Result }\end{array}$ \\
\hline \multirow[t]{3}{*}{ Age (year) } & $18-20$ & $35(34.3)$ & $35(58.3)$ & $0(0)$ & \multirow{3}{*}{$\begin{array}{l}Z^{a}=-5.7 I \\
P<0.00 I\end{array}$} \\
\hline & $21-23$ & $54(53)$ & $21(35)$ & $33(78.6)$ & \\
\hline & $\geq 24$ & $13(12.8)$ & $4(6.7)$ & $9(21.4)$ & \\
\hline \multirow[t]{2}{*}{ Sex } & Male & $45(44.1)$ & $27(45)$ & $18(42.9)$ & \multirow{2}{*}{$\begin{array}{l}\chi^{2}=0.05 \\
P=0.830\end{array}$} \\
\hline & Female & $57(55.9)$ & $33(55)$ & $24(57.1)$ & \\
\hline \multirow[t]{2}{*}{ Marital status } & Single & $92(90.2)$ & $58(96.7)$ & $34(81)$ & \multirow{2}{*}{$\begin{array}{l}\chi^{2 b}=6.89 \\
P<0.001\end{array}$} \\
\hline & Married & $10(9.8)$ & $2(3.3)$ & $8(19)$ & \\
\hline \multirow[t]{3}{*}{ Family income per month(in \$) } & $<300$ & $7(6.9)$ & $6(10)$ & $\mathrm{I}(2.4)$ & \multirow{3}{*}{$\begin{array}{l}Z=-0.38 \\
P=0.698\end{array}$} \\
\hline & $300-600$ & $58(56.9)$ & $32(53.3)$ & $26(61.9)$ & \\
\hline & $>600$ & $37(36.3)$ & $22(36.7)$ & $15(35.7)$ & \\
\hline \multirow[t]{2}{*}{ Residence } & Dormitory & $68(66.7)$ & $42(70)$ & $26(61.9)$ & \multirow{2}{*}{$\begin{array}{l}\chi^{2}=0.73 \\
P=0.393\end{array}$} \\
\hline & $\begin{array}{l}\text { With } \\
\text { family }\end{array}$ & $34(33.3)$ & $18(30)$ & $16(38.1)$ & \\
\hline \multirow[t]{2}{*}{ History of mental illness in the family } & Yes & $9(8.8)$ & $2(3.3)$ & $7(16.7)$ & \multirow{2}{*}{$\begin{array}{l}\chi^{2}=5.45 \\
P=0.031\end{array}$} \\
\hline & No & $93(91.2)$ & $58(96.7)$ & $35(83.3)$ & \\
\hline \multirow[t]{2}{*}{ Interest in the field of study } & Yes & $70(68.6)$ & $44(73.3)$ & $26(61.9)$ & \multirow{2}{*}{$\begin{array}{l}\chi^{2}=1.49 \\
P=0.221\end{array}$} \\
\hline & No & $32(3 \mid .4)$ & $16(26.7)$ & $16(38.1)$ & \\
\hline
\end{tabular}

Notes: ${ }^{a}$ Based on Mann-Whitney U-test. ${ }^{b}$ Based on Chi-square test. 
Table 2 Comparing Levels of Depression Between First- and Final-Year Nursing Students

\begin{tabular}{|c|c|c|c|c|c|c|c|c|}
\hline \multicolumn{3}{|l|}{ Variables } & \multicolumn{4}{|c|}{ Level of Depression } & \multicolumn{2}{|c|}{ Test Result } \\
\hline & & & \multirow{2}{*}{$\begin{array}{l}\text { Non or } \\
\text { Minimal } \\
\text { Number (\%) }\end{array}$} & \multirow{2}{*}{$\begin{array}{l}\text { Mild to } \\
\text { Moderate } \\
\text { Number (\%) }\end{array}$} & \multirow{2}{*}{$\begin{array}{l}\text { Moderate to } \\
\text { Severe } \\
\text { Number (\%) }\end{array}$} & \multirow{2}{*}{$\begin{array}{l}\begin{array}{l}\text { Severe } \\
\text { Number } \\
(\%)\end{array} \\
0(0)\end{array}$} & \multirow{2}{*}{$\begin{array}{l}\begin{array}{l}\text { Median } \\
\left(I^{C}\right)\end{array} \\
I(I)\end{array}$} & Test Statistic \\
\hline \multirow[t]{4}{*}{ Sex } & \multirow[t]{2}{*}{ First year } & Male & & & & & & \multirow{2}{*}{$\begin{array}{l}Z^{a}=-1.38 \\
P=0.166\end{array}$} \\
\hline & & Female & $10(30.3)$ & $16(48.5)$ & $5(15.2)$ & $2(6.1)$ & $\mathrm{I}(\mathrm{I})$ & \\
\hline & \multirow[t]{2}{*}{ Final year } & Male & $13(72.2)$ & $5(27.8)$ & $0(0)$ & $0(0)$ & $0(1)$ & \multirow{2}{*}{$\begin{array}{l}Z=-1.38 \\
P=0.168\end{array}$} \\
\hline & & Female & $13(54.2)$ & $8(33.3)$ & $3(12.5)$ & $0(0)$ & $0(1)$ & \\
\hline \multirow[t]{4}{*}{ Marital status } & \multirow[t]{2}{*}{ First year } & Single & $22(37.9)$ & $25(43.1)$ & $9(15.5)$ & $2(3.4)$ & $\mathrm{I}(0)$ & \multirow{2}{*}{$\begin{array}{l}Z=-0.55 \\
P=0.579\end{array}$} \\
\hline & & Married & $I(50)$ & $I(50)$ & $0(0)$ & $0(0)$ & $0.5(0)$ & \\
\hline & \multirow[t]{2}{*}{ Final year } & Single & $21(61.8)$ & $10(29.4)$ & $3(8.8)$ & $0(0)$ & $0(1)$ & \multirow{2}{*}{$\begin{array}{l}Z=-0.20 \\
P=0.837\end{array}$} \\
\hline & & Married & $5(62.5)$ & $3(37.5)$ & $0(0)$ & $0(0)$ & $0(1)$ & \\
\hline \multirow[t]{6}{*}{ Age (year) } & \multirow[t]{3}{*}{ First year } & $18-20$ & $14(40)$ & $\mid 8(5 \mid .4)$ & $2(5.7)$ & $\mathrm{I}(2.9)$ & $\mathrm{I}(\mathrm{I})$ & \multirow{3}{*}{$\begin{array}{l}\chi^{2 b}=1.90 \\
P=0.386\end{array}$} \\
\hline & & $21-23$ & $7(33.3)$ & $7(33.3)$ & $6(28.6)$ & $\mathrm{I}(4.8)$ & $\mathrm{I}(2)$ & \\
\hline & & $\geq 24$ & $2(50)$ & $\mathrm{I}(25)$ & $\mathrm{I}(25)$ & $0(0)$ & $0.5(1.25)$ & \\
\hline & \multirow[t]{3}{*}{ Final year } & $18-20$ & - & - & - & - & - & \multirow{3}{*}{$\begin{array}{l}\chi^{2}=0.23 \\
P=0.629\end{array}$} \\
\hline & & $21-23$ & $20(60.6)$ & $10(30.3)$ & $3(9.1)$ & $0(0)$ & $0(1)$ & \\
\hline & & $\geq 24$ & $6(66.7)$ & $3(33.3)$ & $0(0)$ & $0(0)$ & $0(I)$ & \\
\hline \multirow[t]{4}{*}{ Residence } & \multirow[t]{2}{*}{ First year } & Dormitory & $19(45.2)$ & $15(35.7)$ & $6(14.3)$ & $2(4.8)$ & $I(I)$ & \multirow{2}{*}{$\begin{array}{l}Z=-1.08 \\
P=0.277\end{array}$} \\
\hline & & With Family & $4(22.2)$ & II (6I.I) & $3(16.7)$ & $0(0)$ & $I(0.25)$ & \\
\hline & \multirow[t]{2}{*}{ Final year } & Dormitory & $16(61.5)$ & $9(34.6)$ & $\mathrm{I}(3.8)$ & $0(0)$ & $0(I)$ & \multirow{2}{*}{$\begin{array}{l}Z=-0.15 \\
P=0.880\end{array}$} \\
\hline & & With Family & $10(62.5)$ & $4(25)$ & $2(12.5)$ & $0(0)$ & $0(I)$ & \\
\hline \multirow{6}{*}{$\begin{array}{l}\text { Family } \\
\text { income per } \\
\text { month(in \$) }\end{array}$} & First year & $<300$ & $0(0)$ & $I(16.7)$ & $4(66.7)$ & $\mathrm{I}(16.7)$ & $2(0.5)$ & $\chi^{2}=14.07$ \\
\hline & & $300-600$ & $16(50)$ & $14(43.3)$ & $9(15)$ & $2(3.3)$ & $0.5(I)$ & $P<0.001$ \\
\hline & & $>600$ & $7(31.8)$ & II (50) & $3(13.6)$ & $\mathrm{I}(4.5)$ & $\mathrm{I}(\mathrm{I})$ & \\
\hline & Final year & $<300$ & $0(0)$ & $I(100)$ & $0(0)$ & $0(0)$ & $I(0)$ & $\chi^{2}=1.23$ \\
\hline & & $300-600$ & $16(6 \mid .5)$ & $9(34.6)$ & $\mathrm{I}(3.8)$ & $0(0)$ & $0(I)$ & $r=0.340$ \\
\hline & & $>600$ & $10(66.7)$ & $3(20)$ & $2(13.3)$ & $0(0)$ & $0(1)$ & \\
\hline Interest in & First year & Yes & $19(43.2)$ & $18(40.9)$ & $7(15.9)$ & $0(0)$ & $I(I)$ & $Z=-1.42$ \\
\hline $\begin{array}{l}\text { the field of } \\
\text { study }\end{array}$ & & No & $4(25)$ & $8(50)$ & $2(12.5)$ & $2(12.5)$ & $I(I .5)$ & $p=0.134$ \\
\hline & Final year & Yes & $15(57.7)$ & $9(34.6)$ & $2(7.7)$ & $0(0)$ & $0(I)$ & $Z=0.68$ \\
\hline & & No & I I (68.8) & $4(25)$ & $I(6.2)$ & $0(0)$ & $0(1)$ & $P=0.496$ \\
\hline
\end{tabular}

Notes: ${ }^{a}$ Based on Mann-Whitney $U$-test. ${ }^{b}$ Based on Kruskal-Wallis $\mathrm{H}$-test. ${ }^{c}$ Interquartile range.

depression being higher in freshman students than in senior students. In line with our results, in the study of Papazisis et al (2014), the third- and fourth-year nursing students had the lowest rate of depression. ${ }^{26}$ Contrary to our results, in the study of Ngasa et al (2017) the prevalence of depression was higher in senior students than in freshman students. ${ }^{27}$ 
Table 3 Depression-Related Factors in First- and Final-Year Nursing Students

\begin{tabular}{|c|c|c|c|c|c|}
\hline \multicolumn{3}{|l|}{ Variables } & \multirow{2}{*}{$\begin{array}{l}\mathbf{O R}^{\mathbf{a}} \\
0.57\end{array}$} & \multirow{2}{*}{$\begin{array}{l}P \text {-value } \\
0.379\end{array}$} & \multirow{2}{*}{$\begin{array}{l}\begin{array}{l}95 \% \mathrm{Cl}^{\mathrm{b}} \\
\text { for OR }\end{array} \\
0.16-2.00\end{array}$} \\
\hline Sex & First year & Male & & & \\
\hline & & Female & 1 & & \\
\hline & Final year & Male & $0.4 I$ & 0.251 & $0.09-1.89$ \\
\hline & & Female & 1 & & \\
\hline \multirow{4}{*}{$\begin{array}{l}\text { Marital } \\
\text { status }\end{array}$} & \multirow[t]{2}{*}{ First year } & Married & 0.86 & 0.924 & $0.04-20.34$ \\
\hline & & Single & 1 & & \\
\hline & \multirow[t]{2}{*}{ Final year } & Married & 0.85 & 0.850 & $0.15-4.80$ \\
\hline & & Single & 1 & & \\
\hline \multirow[t]{6}{*}{ Age (year) } & \multirow[t]{3}{*}{ First year } & $18-20$ & 1 & & \\
\hline & & $21-23$ & 1.15 & 0.819 & $0.34-3.86$ \\
\hline & & $\geq 24$ & 0.91 & 0.940 & $0.09-9.50$ \\
\hline & \multirow[t]{3}{*}{ Final year } & $18-20$ & I & & \\
\hline & & $21-23$ & 0.92 & 0.927 & $0.16-5.16$ \\
\hline & & $\geq 24$ & & & \\
\hline \multirow[t]{4}{*}{ Residence } & \multirow[t]{2}{*}{ First year } & Dormitory & 1 & & \\
\hline & & $\begin{array}{l}\text { With } \\
\text { family }\end{array}$ & 2.63 & 0.173 & $0.66-10.63$ \\
\hline & \multirow[t]{2}{*}{ Final year } & Dormitory & 1 & & \\
\hline & & $\begin{array}{l}\text { With } \\
\text { family }\end{array}$ & 0.70 & 0.667 & $0.14-3.50$ \\
\hline \multirow{4}{*}{$\begin{array}{l}\text { Family } \\
\text { income per } \\
\text { month (in } \\
\$ \text { ) }\end{array}$} & \multirow[t]{2}{*}{ First year } & $<600$ & I & & \\
\hline & & $\geq 600$ & 1.01 & 0.999 & $0.27-3.66$ \\
\hline & \multirow[t]{2}{*}{ Final year } & $<600$ & I & & \\
\hline & & $\geq 600$ & 0.79 & 0.768 & $0.17-3.72$ \\
\hline \multirow{4}{*}{$\begin{array}{l}\text { Interest in } \\
\text { the field of } \\
\text { study }\end{array}$} & \multirow[t]{2}{*}{ First year } & Yes & 0.38 & 0.159 & $0.10-1.46$ \\
\hline & & No & 1 & & \\
\hline & \multirow[t]{2}{*}{ Final year } & Yes & 1.44 & 0.602 & $0.36-5.76$ \\
\hline & & No & 1 & & \\
\hline
\end{tabular}

Notes: a Odds ratio. ${ }^{\mathrm{b} C}$ Confidence interval.

Evidence suggests that at entering university, considering that it is a transient phase from high school to university, nursing students are prone to depression due to reasons such as unfamiliar educational environment, concern over failure or being far from family. ${ }^{6,15,18}$ Causes of depression in senior students include exposure to death, physical and mental illness, and fear of mistakes in clinical practice. ${ }^{16}$
In the present study, there was no significant difference in the level of depression based on place of residence. Evidence suggests that factors such as problems arising from distance from family life, lifestyle changes, dietary changes, and entering a new environment can expose students to depression. ${ }^{8,28}$

In our study, the level of depression was not statistically significant between the two age groups, while a former study showed that with increasing age, the ability to manage mental disorders increases, hence reducing the risk of depression. ${ }^{26}$ However, researchers believe that depression is a phenomenon that can affect students of all ages.

In the current study, the level of depression did not show a statistically significant difference based on sex. This result is consistent with the findings of Papazisis et al (2014). ${ }^{26}$ However, the results of some studies indicate a high level of depression among female students. ${ }^{27,29,30}$ Since educational stressors affect both sexes equally, there is a possibility of depression in both sexes.

In the present study, the difference in the level of depression in terms of household monthly income was statistically significant in the first-year students, but this difference was not significant in the fourth-year students. The results of the study by Moeini et al (2019) indicate a significant relationship between household income and the rate of depressive symptoms among college students. ${ }^{31}$

\section{Limitations}

In this study, the researchers had some limitations. The data collection method was based on self-reporting that could have affected the accuracy of the data. Also, the mental status of the samples while completing the questionnaire may have influenced their responses, which was beyond the control of the researcher. Due to the nature of the crosssectional studies, it is not possible to determine the causeand-effect relationships between the study variables.

\section{Conclusion}

The rate of depression was significantly higher in first-year students than in last year students. Our results highlight the necessity of focusing on students' mental health in addition to providing educational programs. The researchers recommend further studies, especially longitudinal ones, to evaluate the impact of interventional measures on students' depression.

\section{Acknowledgements}

The authors would like to thank all the students who participated in this study. We also extend our thanks to clinical research development center of Imam Reza 
Hospital affiliated to Kermanshah University of Medical Sciences for their kind support.

\section{Disclosure}

The authors report no conflicts of interest in this work.

\section{References}

1. Alizadeh A, Alizadeh E, Mohamadi A. Effectiveness of individual dialectical behavior therapy skills training on major depression. Iran J Psychiatric Nurs. 2013;1(2):62-69.

2. Ibrahim AK, Kelly SJ, Adams CE, Glazebrook C. A systematic review of studies of depression prevalence in university students. J Psychiatr Res. 2013;47(3):391-400. doi:10.1016/j.jpsychires.2012.11.015

3. Amr A, El-Gilany AH, El-Moafee H, Salama L, Jimenez C. Stress among Mansoura (Egypt) baccalaureate nursing students. Pan Afr Med J. 2011;8:26. doi:10.4314/pamj.v8i1.71083

4. Guo YF, Zhang X, Plummer V, Lam L, Cross W, Zhang JP. Positive psychotherapy for depression and self-efficacy in undergraduate nursing students: a randomized, controlled trial. Int J Ment Health Nurs. 2017;26(4):375-383. doi:10.1111/inm.12255

5. Abedini S, Davachi A, Faezeh S, Mahmoudi M, Safa O. Prevalence of depression among nursing and medical students of hormozgan university of medical sciences. Hormozgan Med J. 2006;11(2):139-145.

6. Chernomas WM, Shapiro C. Stress, depression, and anxiety among undergraduate nursing students. Int J Nurs Educ Scholarsh. 2013;10 (1):255-266. doi:10.1515/ijnes-2012-0032

7. Cuttilan AN, Sayampanathan AA, Ho RC. Mental health issues amongst medical students in Asia: a systematic review [2000-2015]. Ann Transl Med. 2016;4:4. doi:10.21037/atm.2016.04.05

8. Moreira DP, Furegato AR. Stress and depression among students of the last semester in two nursing courses. Rev Lat Am Enfermagem. 2013;21(SPE):155-162. doi:10.1590/S0104-11692013000700020

9. Sidana S, Kishore J, Ghosh V, Gulati D, Jiloha RC, Anand T. Prevalence of depression in students of a medical college in New Delhi: a cross-sectional study. Australas Med J. 2012;5(5):247. doi:10.4066/AMJ.2012.750

10. Puthran R, Zhang MW, Tam WW, Ho RC. Prevalence of depression amongst medical students: a meta-analysis. Med Educ. 2016;50 (4):456-468. doi:10.1111/medu.12962

11. Chatterjee S, Saha I, Mukhopadhyay S, Misra R, Chakraborty A, Bhattacharya A. Depression among nursing students in an Indian government college. Br J Nurs. 2014;23(6):316-320. doi:10.12968/ bjon.2014.23.6.316

12. Jimenez C, Navia-Osorio PM, Diaz CV. Stress and health in novice and experienced nursing students. J Adv Nurs. 2010;66(2):442-455. doi:10.1111/j.1365-2648.2009.05183.x

13. Oner Altiok H, Ustun B. The stress sources of nursing students. Educ Sci. 2013;13(2):760-766.

14. Senturk S, Dogan N. Determination of the stress experienced by nursing students' during nursing education. Int $J$ Caring Sci. 2018;11(2):896.

15. Xu Y, Chi X, Chen S, Qi J, Zhang P, Yang Y. Prevalence and correlates of depression among college nursing students in China. Nurse Educ Today. 2014;34(6):e7-e12. doi:10.1016/j.nedt.2013.10.017
16. Uttra AM, Uttra MG, Rauf A, Uttra MM, Hasan UH, Batool A. Prevalence of depression: a cross-sectional study among MBBS students of Sargodha medical college, Sargodha Pakistan. Prof Med J. 2017;24(03):482-489. doi:10.17957/TPMJ/17.3708

17. Kumar GS, Jain A, Hegde S. Prevalence of depression and its associated factors using beck depression inventory among students of a medical college in Karnataka. Indian J Psychiatry. 2012;54 (3):223. doi:10.4103/0019-5545.102412

18. Christensson A, Vaez M, Dickman PW, Runeson B. Self-reported depression in first-year nursing students in relation to socio-demographic and educational factors: a nationwide cross-sectional study in Sweden. Soc Psychiatry Psychiatr Epidemiol. 2011;46(4):299-310. doi:10.1007/ s00127-010-0198-y

19. Tung YJ, Lo KK, Ho RC, Tam WS. Prevalence of depression among nursing students: A systematic review and meta-analysis. Nurse Educ Today. 2018;63:119-129. doi:10.1016/j.nedt.2018.01.009

20. Brouwer D, Meijer RR, Zevalkink J. On the factor structure of the beck depression inventory-II: G is the key. Psychol Assess. 2013;25 (1):136. doi:10.1037/a0029228

21. Whisman MA, Richardson ED. Normative data on the beck depression inventory-second edition (BDI-II) in college students. J Clin Psychol. 2015;71(9):898-907. doi:10.1002/jclp.22188

22. Campos RC, Gonçalves B. The Portuguese version of the beck depression inventory-II (BDI-II). Eur J Psychol Assess. 2011;27:258-264. doi:10.1027/1015-5759/a000072

23. Khan AA, Marwat SK, Noor MM, Fatima S. Reliability and validity of beck depression inventory among general population in Khyber Pakhtunkhwa, Pakistan. J Ayub Med Coll Abbottabad. 2015;27(3):573-575.

24. Ghassemzadeh H, Mojtabai R, Karamghadiri N, Ebrahimkhani N. Psychometric properties of a persian-language version of the beck depression inventory-second edition: BDI-II-Persian. Depress Anxiety. 2005;21(4):185-192. doi:10.1002/(ISSN)1520-6394

25. Huber SJ, Freidenberg DL, Paulson GW, Shuttleworth EC, Christy JA. The pattern of depressive symptoms varies with progression of Parkinson's disease. J Neurol Neurosurg Psychiatry. 1990;53 (4):275-278. doi:10.1136/jnnp.53.4.275

26. Papazisis G, Nicolaou P, Tsiga E, Christoforou T, SapountziKrepia D. Religious and spiritual beliefs, self-esteem, anxiety, and depression among nursing students. Nurs Health Sci. 2014;16 (2):232-238. doi:10.1111/nhs. 12093

27. Ngasa SN, Sama CB, Dzekem BS, et al. Prevalence and factors associated with depression among medical students in Cameroon: a cross-sectional study. BMC Psychiatry. 2017;17(1):216. doi:10.1186/ s12888-017-1382-3

28. Shin SH. The effect of academic stress and the moderating effects of academic resilience on nursing students' depression. J Korean Acad Soc Nurs Educ. 2016;22(1):14. doi:10.5977/jkasne.2016.22.1.14

29. Rathnayake S, Ekanayaka J. Depression, anxiety, and stress among undergraduate nursing students in a public university in Sri Lanka. Int J Caring Sci. 2016;9(3):1020-1032.

30. Najafi Kalyani M, Jamshidi N, Salami J, Pourjam E. Investigation of the relationship between psychological variables and sleep quality in students of medical sciences. Depress Res Treat. 2017;2017:1-6. doi:10.1155/2017/7143547

31. Moeini B, Bashirian S, Soltanian AR, Ghaleiha A, Taheri M. Prevalence of depression and its associated sociodemographic factors among Iranian female adolescents in secondary schools. $B M C$ Psychol. 2019;7(1):25. doi:10.1186/s40359-019-0298-8 


\section{Publish your work in this journal}

Psychology Research and Behavior Management is an international, peer-reviewed, open access journal focusing on the science of psychology and its application in behavior management to develop improved outcomes in the clinical, educational, sports and business arenas. Specific topics covered in the journal include: Neuroscience, memory and decision making; Behavior modification and management; Clinical

applications; Business and sports performance management; Social and developmental studies; Animal studies. The manuscript management system is completely online and includes a very quick and fair peer-review system, which is all easy to use. Visit http://www. dovepress.com/testimonials.php to read real quotes from published authors. 